\title{
Sommeren som endret alt
}

\author{
Barnevernet og grønn omsorg hos fosterfamilie berget fremtidsutsiktene for fylkeslegen. \\ Selv sier han: - Jeg er bare en enkel gutt fra landet som liker å være med på å \\ bestemme.
}

Fylkeslege Henning Aanes sitter tilbakelent på kontoret i Statens hus i Bodø og ser ut over moloen, småøyene og Saltenfjorden. Utsikten gjør inntrykk på de fleste. Selv gjorde han inntrykk på både gårdbrukere og byråkrater som var samlet til en stor konferanse om prosjektet «Inn på tunet» tidligere $\mathrm{i}$ år. Inn på tunet - tidligere kjent som grønn omsorg - er tilrettelagte tilbud der gårdsbruk er rammen. I nært samarbeid med oppvekst-, helse- og sosialsektoren i kommunen kombineres landbruk med læring og omsorg. Målgruppen er folk med ulike funksjonshemminger, rusproblemer eller spesielle behov. Mange av tilhørerne på konferansen ventet at fylkesmannens utsendte skulle foredra om statlige regler og systemer, men i stedet fikk de servert historien om en ni år gammel gutt som ble plassert på en gård mange mil hjemmefra. Henning Aanes fortalte varmt om gårdens folk og dyr, om bygda, om naturen og muligheten til å rette opp et skakkjørt gutteliv. - Dette er historien om min barndom, avsluttet han innlegget sitt. Han markedsfører grønn omsorg og Inn på tunet så snart han har anledning.

- Det er ikke så lenge siden jeg innså at det var denne type omsorg jeg selv ble utsatt for som barn, humrer han. - Fylkesmannens landbruksavdeling har jobbet med dette i mange år, jeg har vært med på tverrfaglige møter og har lest mye om temaet, men det tok en tid før jeg koblet Inn på tunet med min egen oppvekst. Innen mitt fagfelt er folkehelsebegrepet stadig viktigere. Mye handler om barns oppvekstvilkår når vi arbeider med voksnes rusmisbruk eller psykiske problem. Jeg har aldri jobbet med barn direkte, annet enn som fastlege og kommunelege, men prøver å vektlegge barnas interesser. Hvis vi hele tiden setter deres behov først, får flere barn muligheten til å klare seg, mener Aanes.

\section{Barn uten barndom}

Selv klarte Henning Aanes seg takket være voksne som tok ansvar. Han ble født i Narvik i 1950. - Ekte framnesgutt, poengterer han. Aller helst vil han fortelle fra årene etter at han fylte ni år. Før den tid førte foreldrenes skilsmisse og en omflakkende tilværelse til at røttene ikke ble særlig dype i Narvik. Farsan og morsan i Narvik ble erstattet av mor og far på gårdsbruket på Tjeldøya. Torbjørn og Magda Pedersen var født i henholdsvis i 1908 og 1903, og var dermed godt voksne da de overtok omsorgen for vesle Henning. Selv om ikke familielivet var ordinært, presenterer han en moderne familiestruktur. - Jeg har ni søsken, sier han og gjør ikke forskjell på tre helsøsken, fire halvsøsken og to fostersøsken. Men det er fra familien og småbruket på Myklebostad han har sine minner og erfaringer. - Her fikk jeg være med i dagliglivet i bygda og på gården. Jeg visste det var bruk for meg, lærte å mestre mange praktiske oppgaver og fikk kunnskaper fra en hverdag rik på opplevelser. Nærkontakten med dyrene på gården gjorde meg godt og Magda og Torbjørn lærte meg respekt for både folk og arbeid. Bygda var på mange måter todelt, der den ene delen var læstadianere, men jeg erindrer ikke dette som problematisk. Mor og far snakket ikke om ufred i bygda. Kanskje var det konflikter, men jeg husker best samholdet. Bygdedyret så jeg heller ingenting til. Det møtte jeg faktisk ikke før jeg studerte på Blindern.

\section{Sommeren som endret alt}

Det var barnevernet som fanget opp Henning Aanes som niåring. Planen var at han skulle være på Myklebostad sommeren 1959, men han flyttet ikke fra gården før han ble 19 år. Ei lita jente kom sammen med ham fra Narvik og en ung tysk gutt bodde også på småbruket denne sommeren, men reiste hjem da høsten kom. - Jeg vet ikke hvorfor jeg ble igjen, sier Henning Aanes. - Ingenting av barnevernets innsats kan dokumenteres, da alle sakspapirene forsvant $i$ en brann ved Narvik-kontoret.
Myklebostad var en veiløs bygd på denne tiden, og sannsynligvis huset grendene her under hundre personer. Far Torbjørn drev med gårdsbruk, men var mye borte på fiske og hvalfangst. Mor Magda bestyrte den ene av bygdas to landhandler og drev et allsidig selvbergingsbruk. Ute var det arbeid med jorda og høyonn, bærplukking, grønnsaksdyrking og vedhogst. I tillegg var det sauer og ullarbeid, høns og eggsalg og innkjøpt kalv til oppfôring. - Melk kjøpte vi hos ho Halldis i Rusvika, sier bygutten, som har full oversikt over alt som rørte seg på et småbruk gjennom årstidene. Hest var det ikke på bruket. - En nydelig grå diesel Ferguson gjorde nytten, mimrer Aanes. Unggutten kjørte traktoren lenge før noen kom på tanken om trafikalt grunnkurs. - Det var jo nyttig at jeg kunne hente varene til ho mor og kjøre den vesle turen mellom kaia og landhandelen, smiler han.

\section{Arbeidsomt bygdeliv}

- Jeg var en utemmet bygutt både i tenkeog væremåte og må ha vært både en prøvelse og et mareritt, spekulerer Henning Aanes. Var Magda og Torbjørn formelt fosterforeldre? Fikk de veiledning? Han har ikke svar, vet bare at han ble behandlet på samme måte som sine eldre fosterbrødre. Broren Arve var ivrig medlem i Varden 4Hklubb og fikk med Henning Aanes på aktivitetene. - På den tiden var $4 \mathrm{H}$ konkurranseorientert med læringsformål. Det var sosiale aktiviteter, friluftsliv, åkerflekkansvar og høstfest. Far Torbjørns arbeid trengte også et par ekstra never når garnene skulle bøtes. - Vi satt på kjøkkenet, og jeg tror bøteknuten vil sitte i fingrene for alltid, smiler Aanes, som mener han tross mange praktiske gjøremål aldri ble en praktiker. Det var flust av arbeidsoppgaver året rundt. Lofotfisket skulle forberedes, og dette tok nesten like lang tid som selve fisket.

- Faren ville spare alle guttene sine for det harde livet han selv levde og oppfordret ikke til å tenke på fiskeryrket som levevei. - Mor og far var forutseende og jobbet for at vi alle skulle stå sterkt i møtet med utdanningssamfunnet. Storebror Endre var den første på Myklebostad som gjennomførte gymnaset, bror min Arve var nummer to og jeg var nummer fire. - Det var ikke noe 


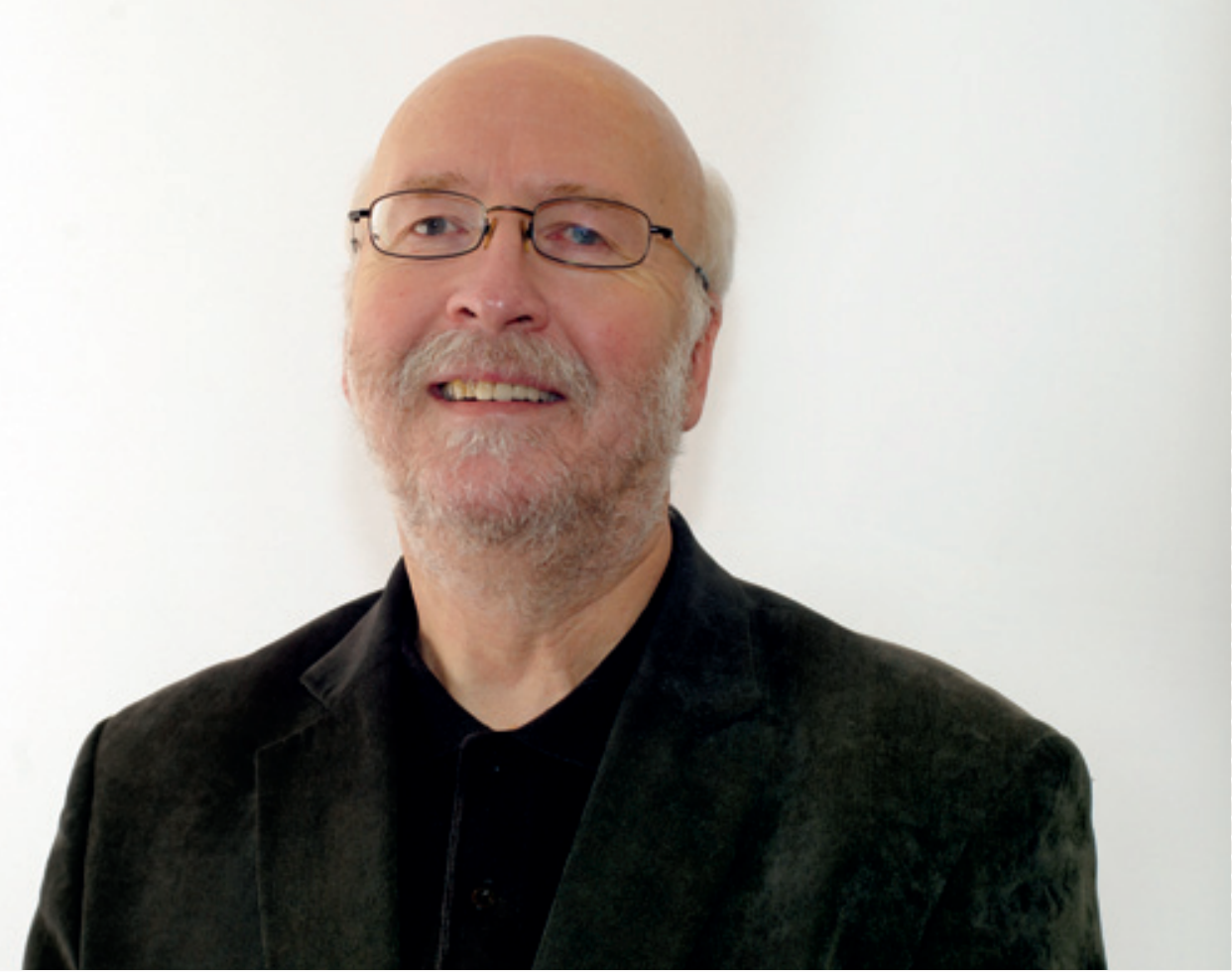

Henning Robert Aanes

Født 8. august 1950 i Narvik

- Cand.med. Universitetet i Bergen 1978

- Spesialist i samfunnsmedisin 2004

- Master of Public Administration ved Copenhagen Business School 2003

- Allmennlege/kommunelege I. Hadsel kommune 1981-2003

- Regionoverlege Telenor 1994-97

- Fylkeslege i Nordland 2004-

- Medisinskkyndig fast rettsmedlem i Trygderetten 2009-

Foto Anders Vanderloock/SCANPIX

press, men vi fikk støtte hele tiden. Magda holdt alle tråder, hadde disiplin, var streng og rettferdig. Torbjørn var en lun og mild mann som satte spor etter seg både $\mathrm{i}$ bygda og i fiskermiljøet. To kloke mennesker som ofte ble rådspurt av sine sambygdinger. De arbeidet nesten bestandig, men Henning Aanes husker ikke at de var spesielt travle.

\section{Lærdom og studier}

Hverdagen var i det hele tatt mindre preget av stress og tidsklemme. Aviser og radio sto for nesten all underholdning og informasjon, og bygda ble opplevd som en snill og fredelig plass. - Jeg var en fremmed fugl og en uoppdragen erkebygutt, men husker ikke annet enn at bygda tok godt imot meg. I helgene samlet vi ungdommene oss hjemme hos hverandre, og det var alltid fredelig. Magda ville likevel holde på guttene sine, og de bodde på gården mens de tok realskole per korrespondanse. Siden gikk veien til folkehøyskole i Sømna og gymnas i Narvik. Bylivet fristet ikke i helgene. Så snart skolen sluttet på fredagene, samlet en lystig ungdomsgjeng seg om bord i MS Tjeldøy.

Endelig ventet den store verden. Halvannet år på Åsgård psykiatriske sykehus på lukket mannsavdeling og examen philosophicum ga poeng til medisinstudier. I 1971 ble adressen Oslo, men Henning Aanes fikk aldri tak på byen. Å være studentpolitisk engasjert uten å være marxist-leninist gjorde ikke saken bedre. - Det var til tider hatske utfall, knallharde og slitsomme konfrontasjoner, minnes Aanes. Etter tre år var det nok. Han meldte overgang til Bergen, der medisinstudiene ble fullført. Siviltjenesten ble gjennomført på psykiatrisk sykehus i Trondheim, og allmennlegedrømmen førte ham til Lyngen, Stokmarknes og Melbu. Her ble han kommunelege før Telenor trengte ham som ansvarlig for helse, miljø og sikkerhet (HMS). Turen gikk videre til Sosial- og helsedirektoratet, før han i 2004 ble fylkeslege i Nordland.

Fra leiligheten i Bodø pendler han til kona i Melbu, men ofte går turen sørover til farfars gull, vesle Vilje Amalie som kom til verden før jul i 2008.

\section{Regelstyrt omsorg?}

Både privat og $\mathrm{i}$ arbeidssammenheng er det tydelig at barn står i fokus. En av fylkeslegenes viktigste oppgaver er å se til at alle regler blir fulgt $i$ helsevesenet og at såkalte avvik lukkes. Hvordan passer Inn på tunet inn i dette systemet? - Det er klart at tilbudet skal holde god kvalitet, men jeg er redd for et gjennomregulert system. Reglene skal beskytte folk, men for mange regler kan kvele både gode samfunnsformer og -aktiviteter. Kommunene skal se til at de private tilbudene innen helse, omsorg og utdanning holder mål. De ansvarlige trenger systemer, men det er grenser for hvor mye hverdagen på et gårdsbruk kan reguleres. Vi må finne pragmatiske ordninger. Barn skal være sikre, men de skal oppleve frihet, mestring og selvstendighet. Slik er bondeyrket. Man er sin egen herre på godt og vondt. Bonden finner løsninger og må sørge for at alt fungerer.

\section{Hva koster en oppvekst?}

Økonomisk skal regnskapet også gå i hop. - Vi må se både på livsregnskap og årsregnskap, insisterer fylkeslegen. - Kommunen må se lenger enn neste års budsjett. Hvor mye skal en kommune se seg tjent med å investere i et ungt liv? Hele samfunnet tjener på at barn som trenger det, får hjelp. Hva koster det å la være i perioder med dårlig kommuneøkonomi å hjelpe dem som trenger det? Vi må omfordele noen ressurser, vi må finne barna og hjelpe dem tidlig. Foreldreretten er ingen eiendomsrett. Mange ser, men venter for lenge.

For meg er slike saker uhyre tunge å lese om og å oppleve. Barn er lojale og tåler mye vanskjøtsel og omsorgssvikt. Vi må alle ta ansvar. Spesielt er jeg opptatt av helsestasjonene. Helsesøstrenes rolle er svært viktig og bør være en krumtapp i kommunens helseforebyggende arbeid. De tilbyr et lavterskeltilbud og har status blant barn og unge.

For min del arvet jeg skoleflinkhet av mine biologiske foreldre, men Torbjørn og Magda på Myklebostad ga meg ro, opplevelser, arbeidsglede og oppfølging med skolearbeidet. Jeg vet ikke om jeg hadde klart meg uten ny far, mor og søsken, gården og bygda. Jeg tror utsiktene hadde vært dårlige.

\section{Ingeborg Tangeraas}

ingtang@online.no

Øvre Bjørkåsen 39

8074 Bodø 